\title{
Tüketim Karşıtı Bireylerin Çevreci Reklamlara Olan Tutumları
}

\section{Yelda Ülker}

\section{Öz}

Günümüzde hızlı ve aşırı tüketim sık görülen bir davranıştır. Fakat bu tüketim tarzı hem bireyleri mutsuz etmekte hem de doğaya zarar vermektedir. Bu durum da bilinçlenen tüketicilerin tüketime karşı davranışlar sergilemelerine aracı olabilmektedir. Diğer bir deyişle günümüzde tüketimden zevk almayan ve bilinçsiz tüketim yapmayan tüketim karşıtları bulunmaktadır. Tüketimden zevk almayan, tüketmeye direnen bu bireyler genellikle tutumlu olup, minimal bir yaşam tarzını benimsemekte ve gönüllü sadeliği tercih etmektedir. Bu tarz bir yaşamı benimseyen tüketim karşıtları çevreci davranışlar sergileyip, çevre dostu markaları tercih edebilmektedir. Bu bağlamda araştırmada tüketim karşıtı olan bireylerin materyalizm, tutumluluk ve gönüllü sadeleşme eğilimleri ile çevreci reklamlara olan tutumları, yeşil marka bilinci ve çevreci ürün satın alma niyetleri arasında anlamlı bir ilişkinin olup olmadı̆̆ı irdelenmektedir. Araştırmada veri toplama tekniği olarak anket uygulanmıştır. Elde edilen bulgulara göre tüketicilerdeki materyalizm eğilimi ile çevreci reklamlara olan tutumları, yeşil marka bilinçleri ve çevreci ürünleri satın alma niyetleri arasında anlamlı bir ilişki bulunmuştur. Ayrıca araştırmada tüketicilerdeki tutumluluk eğilimi ile çevreci reklamlara olan tutumları ve çevreci ürünleri satın alma niyetleri arasında da anlamlı bir iliş̧ki tespit edilmiştir. Bunların yanı sıra tüketicilerin gönüllü sadeleşmeleri ile tüketicilerin çe vreci ürünleri satın alma niyetleri arasında da anlamlı bir ilişki vardır.

Anahtar Sözcükler: Tüketim Karşıtlığı, Gönüllü Sadeleşme, Çevreci Reklamlar, Yeşil Marka Bilinci, Satın Alma Niyeti

\author{
YELDA ÜLKER \\ Dr. \\ yeldaulker@hotmail.com \\ ORCID ID: 0000-0001-8105-2686
}

SELÇUK ILETIŞIM DERGISI 2021; 14(2): 784-804

doi: 10.18094/ JOSC.877887

Geliş Tarihi: 10.02.2021 Kabul Tarihi: 09.03.2021 Yayın Tarihi: 25.04.2021 
Anti- Consumption Individuals' Attitudes Towards Environmental Advertisements
JOURNAL OF SELÇUK

COMMUNICATION 2021;

14(2): 784-804

doi: 10.18094/ JOSC.877887

\section{Yelda Ülker}

\section{ABSTRACT}

Today, waste-based consumption is a very common bevahior of consumers. However, this consumption style both makes individuals unhappy and harms the nature. This situation causes consumers to have a negative attitude towards consumption. In other words, today there are consumers who do not enjoy consumption and do not consume unconsciously. These individuals who do not enjoy consumption and resist consumption are generally thrifty, adopt a minimal lifestyle and prefer voluntary simplicity. Consumers who adopt such a lifestyle can display environmentally friendly behaviors and prefer environmentally friendly brands. In this context, the research examines whether there is a significant relationship between the materialism, thrift and voluntary simplification tendencies of individuals against consumption and their attitudes towards environmental advertisements, green brand awareness and their intention to purchase environmentally friendly products. According to the findings, there is a meaningful relationship between the materialism tendency of the consumers and their attitudes towards environmental advertisements, their green brand awareness and their intention to buy environmentally friendly products. Purchasing intentions about a meaningful relationship between the attitude tendency of consumers and their attitudes towards environmental advertisements and green purchasing intentions in the research on the subject. In addition, research on a meainingful relationship between consumer simplification of consumers and their intention to buy environmentally friendly products.

Keywords: Anti- Consumption, Voluntary Simplification, Environmental Advertisements, Green Brand Awareness, Purchase Intention

\section{YELDA ÜLKER}

Dr.

yeldaulker@hotmail.com

ORCID ID: 0000-0001-8105-2686

JOURNAL OF SELÇUK COMMUNICATION 2021; 14(2): 784-804

doi: 10.18094/ JOSC.877887 


\section{Giriş}

Kapitalizm ile birlikte tüketiciler aşırı tüketim davranışı sergileyen tüketiciler, genellikle tüketimlerinden haz alma amacı gütmekte, davranışlarında aşırıya kaçmakta ve rasyonel faydaları doğrultusunda hareket etmemektedirler. Bu durum da çevrenin kirlenmesini, doğal hayatın riske girmesini ve kaynakların yok olmasını hızlandırmaktadır. Diğer bir deyişle tüketicilerin bitmeyen talepleri ve aşırı tüketimleri doğal felaketlerin oluşmasına sebep olabilmektedir. Fakat aşııı ve bilinçsiz tüketimin oluşturduğu bu sorunlar bazı tüketicilerin dikkatini çekmektedir. Bu tüketiciler, tüketmekten zevk duymamakta, tüketime direnmekte ve hatta tüketime karşı öfke gibi olumsuz duygular beslemektedir. Tüketim karşıtı bu bireyler tüketim kültürüne ve tüketimle oluşturulan anlamlara karşı gelmektedirler. Bu bireyler genellikle materyalizme karşı olmakta, gönüllü sadeliğe yönelmektedir. Minimalizmi benimseyen tüketiciler tüketimlerinde tutumlu davranmaktadır. Tüketim karşıtları tüketime direnmekte, tasarruf etmekte ve kaynaklarını korumaktadır. Ayrıca tüketmeme felsefesini benimsemiş bu bireyler, kullandıkları ürünlerin ömürlerini uzatmaya çalışmakta, bozulanları tamir etmekte veya üründe değişiklik yaparak farklı alanlarda yeniden kullanmaktadır. Maddiyata önem vermeyen, sade ve minimal bir yaşam tarzını benimseyen tüketim karşıtları, basit ambalajlı, işlevselliği fazla olan, rasyonel faydası olan ürünleri tercih etmektedir. Diğer bir deyişle tüketim karşıtları bilinçli tüketim davranışı sergilemekte, karbon ayak izlerine dikkat etmekte ve daha az atık üretmeye çalışmaktadır (Palafox, 2020, s. 87). Bu bağlamda tutumlu davranan, gönüllü sadeleşmeyi seçen ve minimal bir yaşam tarzına sahip tüketim karşıtları etik ve sembolik kaygıları ve doğacı tutumları dolayısıyla yerel ürünleri tercih etmekte, organik ürünlere yönelmekte, yeşil enerji şirketlerini tercih etmekte ve yeşil markaları kullanmaktadır (Albinsson, Wolf, \& Kopf, 2010, s. 415; Chatzidakis \& Lee, 2012, s. 196).

Tüketicilerin bilinçlenmesiyle birlikte çevre konularına karşı daha hassas olması, markaların da dikkatini çekmektedir. Bu durum da markaların çevre odaklı stratejiler geliştirmelerine sebep olmaktadır. Özellikle 80'lerden sonra çevre ve toplumsal olaylara olan farkındalığın artması, doğayı korumaya yönelik çevreci reklamların sayısının artmasını da sağlamıştır. Çevreci reklamlar için doğa sorunlarını dikkate alan, çevre kirlenmesini önlemeye veya iyileştirmeye yönelik iddialarda bulunan reklamlar tanımı yapılabilir. Bir diğer deyişle çevreci reklamlar için markanın açıkça veya ima yoluyla çevresel sorumluluk aldığına dair mesajını ilettiği reklam türü denilebilir. Bu tarz reklamlarda markanın çevre dostu olduğunu belirtmek için 
genellikle "daha az atık", "çevre dostu", "yeniden kazanılabilir" veya "geri dönüştürülebilir" gibi ifadeler yer almaktadır (Alnıaçık, 2009, s. 88-89; Karna, Juslin, Ahonen, \& Hansen, 2001, s. 61). Böylece çevreci reklamlar hedef kitlenin algısını değiştirmekte, bilinç oluşturmakta ve markanın satın alınmasını sağlamaktadır. Fakat tüketiciler markaların çevresel faydalarını öven iddiaları yanıltıcı veya aldatıcı bulabilir. Bu sebeple tüketicilerin markaların çevre dostu olduklarılyla ilgili iddialarına inanması ve güvenmesi önemlidir. Çevreyi koruma iddiasında bulunan reklamların tüketim karşıtı tüketicilerin de dikkatini çektiği söylenebilir. Bununla birlikte doğayı korumaya yönelik tüketim davranışı sergileyen tüketim karşıtlarının çevre konusundaki farkındalıklarının daha yüksek olduğu düşünülebilir.

Yukarıdaki bilgiler ışığında araştırmanın temel amacını tüketicilerin tüketim karşıtı̆ı̆ının alt boyutları olan materyalizm, tutumluluk ve gönüllü sadeleşme eğilimleri ile çevreci reklamlara olan tutumları, yeşil marka bilinci ve çevreci ürün satın alma niyetleri arasında anlamlı bir ilişki olup olmadığının irdelemesi oluşturmaktır. Bu amaç doğrultusunda 389 katılımcıdan anket aracılığıyla veri elde edilmiştir.

\section{TÜKETIM KARŞITLIĞI KAVRAMI}

Günümüzde kapitalizmle birlikte aşırı tüketim ve küreselleşme hızlıca yayılmaktadır. Küresel hale gelen aşırı tüketimle birlikte çevresel kirlenme, kaynakların azalması veya yok olması vb. doğanın riske girmesine yol açan sorunlar ciddi boyutlara ulaşmıştır. Ortaya çıkan bu sorunların sebebi olarak tüketicilerin aşıı tüketim ve bitmeyen talepleri gösterilebilir (Iwata, 2006, s. 557). Bu durum tüketim kavramının modernlik, zenginlik ve özgürlükle doğa ve insan kavramlarının ise sömürme/sömürülme ekseninde düşünülüp, tartışılmasına yol açmaktadır (Karaboğa, 2016, s. 2075). Bu bağlamda günümüzde tüketimden zevk almayan, aşırı tüketim yapmayan tüketim karşıtları bulunmaktadır. Zavestoski'nin (2002, s. 121) yapmış olduğu tanıma göre tüketim karşıtlığı, tüketimden zevk alamamak, tüketime direnmek ve hatta tüketime karşı öfke duymaktır. Penaloza ve Price $(1993$, s. 123) ise tüketim karşıtlığını bireylerin tüketim kültürüne ve kitlesel üretilen anlamlara karşı olması olarak tanımlamaktadır.

Nepomuceno ve Laroche'un (2015) yapmış olduğu çalışmaya göre tüketim karşıtı bireyler tutumluluk, gönüllü sadelik ve minimalist yaşam tarzı sergilemektedir. Tutumluluk yaşam tarzına sahip tüketiciler, ekonomik mal ve hizmetleri becerikli bir şekilde kullanma özelliğine sahiptir (Lastovicka, Bettencourt, Hughner, \& Kuntze, 1999, s. 88). Tutumlu tüketiciler, tüketmeye direnip, tasavvuf ederken 
aynı zamanda bu durumdan zevkte almaktadır (Rick, Cynthia, \& Loewenstein, 2008). Tutumluluk kavramı, bireylerin para harcamada kendilerini ne ölçüde sınırladıklarıyla ilgilidir. Tutumlu olan bireyler paralarını harcamada, kaynaklarını korumada sıkı olmanın yanı sıra, sahip oldukları şeylerle yaşamaya çalışmaktadırlar (Kasser, 2005, s. 358). Tüketim karşıtları aynı zamanda gönüllü sadeliği benimseyen bir yaşam tarzına da sahiptir. Gönüllü sadeleştiriciler, aşırı tüketim yapmaktan kaçınmaktadırlar (Kaynak \& Eksi, 2011, s. 37). Ayrıca gönüllü sadeleştiriciler, adil ticaret ve yerel üretim yapan, çevreyi koruyan markaları seçmektedirler (Shaw \& Moraes, 2009, s. 216). Boujbel ve D'astous'un (2012, s. 487) çalışmasına göre gönüllü sadelikte bireylerin tüketim arzularını fark etmeleri ve tüketim davranışları üzerinde kontrol sağlamaları önemli bir motivasyon kaynağıdır. Bununla birlikte gönüllü sadelik yaşam tarzını kabul etmiş bireyler, kullandıkları ürünlerin ömürlerini uzatmaya çalışmakta, bu ürünleri farklı alanlarda yeniden kullanmakta veya tamir etmektedir (Shaw \& Moraes, 2009, s. 216). Ayrıca gönüllü sadeleştiriciler basit ambalajlı, işlevselliği yüksek olan, rasyonel fayda sağlayan, küçük esnaf tarafından veya yerel ürünleri satın almakta veya kendi yaptıkları ürünleri kullanmaktadır (Shama, 1981, s. 129). Tüketim karşıtları için önemli olan bir diğer yaşam tarzı da materyalizmin karşıtı olarak tanımlanabilen minimalizmdir (Nepomuceno \& Laroche, 2015). Materyalizmin maddi olana verilen öncelik üzerinden düşünülebilir (Belk, 1984). Materyalist bireyler genellikle maddi malları edinmeyi hayatlarının temel amacı olarak görmekte, sahip oldukları maddiyatla ve onların sayılarıyla mutlu olmaktadır (Daun, 1983; Belk, 1984). Ayrıca sahip olmanın mutluluğun kaynağı olduğuna inan materyalistler, tüketime daha çok meyletmektedir (Nepomuceno \& Laroche, 2015, s. 3). Materyalizmin karşıtının olarak kabul edilebilen minimalizm, aşırı ve bilinçsiz tüketime karşı gösterilen bir tepki olarak tanımlanmakta (Dopierala, 2017, s. 71), gönüllü sadelik kavramına oldukça benzemenin yanı sıra gönüllü sadelik daha geniş anlamda olup, 1970'li yıllara uzanan, köklü bir tarihi vardır (Taş, 2020, s. 52). Innsanların bilinçli olarak daha az eşyayla yaşadığı, düşük tüketimli bir yaşam tarzı olan minimalizm, bireylerin hayatında önemli bir yere sahip olmayan, değer katmayan, fazlalıkları, eşyaları, fikirleri bırakmasıdır (Lloyd \& Pennington, 2020, s. 121). 2008 yılından sonra popülerleşen ve eşyaların azaltılması odaklı bir yaşam tarzı olan minimalizmde (Taş, 2020, s. 52), ortak kurallar ya da prensipler olmadığı için bu tecrübe bireyden bireye farklılık göstermektedir. Minimalist yaşam tarzını benimsemiş bireyler, ihtiyaçlarına göre daha az ve gerekli olan ihtiyaçlara yönelmektedir. Bu bireyler tüketim seçimlerinde daha bilinçli hareket etmekte, karbon ayak izlerini izlemekte veya ne kadar atık ürettiklerini fark etmektedir (Palafox, 2020, s. 87). 
Tutumluluk, gönülü sadeleşme ve materyalizmden uzak minimalist yaşam tarzını benimseyen tüketim karşıtları, çevresel sorunlar, insan hakları ihlali ve ekonomik adaletsizlik gibi faktörlerden dolayı tüketmemekte, tüketimlerini azaltmakta ve seçici tüketim davranışı sergilemektedir (Nepomuceno \& Laroche, 2015; Basci, 2014, s. 162). Diğer bir deyişle etik, sembolik ve çevreye duyulan kaygılar tüketicilerin aşırı tüketim kültürüne karşı direnmelerine sebep olabilmektedir (Albinsson, Wolf, \& Kopf, 2010, s. 415; Chatzidakis \& Lee, 2012, s. 196). Tüketim karşıtı bireyler, genellikle çevre konusunda hassas davranmakta, yerel üreticileri tercih etmekte, organik ürünleri tüketmekte ve yeşil enerji şirketlerini tercih etmektedir (Basci, 2014, s. 164). Ayrıca tüketim karşıtı bireyler, gereksiz ışıkları söndürme, araba kullanmama, sifon kullanırken temiz su harcamama, tarım ilacı satın almama gibi davranışlar sergilemektedir (Black \& Cherrier, 2010, s. 444).

\section{ÇEVRECI REKLAM KAVRAMI}

Tüketicilerin ekolojik çevre konularına dikkat etmeye başlamasıyla birlikte markalar da toplumun bu hassasiyetine kayıtsız kalamamış ve çevre odaklı stratejiler geliştirmeye başlamıştır (Çam \& Ürün, 2019). Özellikle 1980'lerin sonlarına doğru çevre sorunlarına olan farkındalığın artması, doğayı koruma mesajlarının yer aldığı çevreci veya diğer adıyla yeşil reklamların sayısının da artmasına sebep olmuştur (Ulusu \& Köksal, 2012, s. 4644; Zinkhan \& Carlson, 1995, s. 1). Bu bağlamda çevreci veya yeşil reklam için markanın doğa sorunlarını dikkate aldığını, çevre kirlenmesini önlemeye ve çevreyi iyileştirmeye, korumaya çalıştığını iddia ettiği reklamlar tanımı yapılabilir (Alnıaçık, 2009, s. 53). Banerjee, Gulas ve lyer (1995, s. 22) çevreci reklamları, markanın açıkça veya ima yoluyla çevresel sorumluluk aldığını belirttiği reklamlar şeklinde açıklamaktadır. Çevreci reklamlarda, markanın doğaya olan etkisi, çevreci özellikleri ve faydaları gibi iddialar bulunmaktadır. Örneğin çevreci reklamlarda markanın doğa dostu olduğunu tüketicilere anlatmak için "daha az atık", "çevre dostu”, "yeniden kazanılabilir" veya "geri dönüştürülebilir" gibi ifadeler kullanılmaktadır (Alnıaçık, Yılmaz, \& Alnıaçık, 2010, s. 88-89; Karna, Juslin, Ahonen, \& Hansen, 2001, s. 61). Çevreci reklamlar tüketicilerin çevre dostu markaları satın alma niyetini etkilemekte önemlidir. Birçok çevreci reklam doğa dostu mesajı sayesinde tüketicilerin zihninde iz bırakmaktadır (Carlson, Grove, \& Kangun, 1993, s. 28). Diğer bir deyişle çevreci ürünler hakkında bilgi veren çevreci reklamların temel amacı, hedef kitlenin algısını değiştirmekte, bilinç oluşturmak ve doğa dostu markaların satın alınmasını sağlamaktır (Rahbar \& Wahid, 2011, s. 76). Zinkhan ve Carlson'a (1995, s. 2) 
göre de çevreyle ilgili endişe duyan tüketiciler daha çok çevreci markaları satın alma niyeti göstermektedir. Fakat Hassan ve Valenzuela'nın (2016, s. 174-175) yapmış olduğu çalışmaya göre katılımcıların \%22,2'sinin çevreci reklamları nadiren fark etmektedir. Araştırmaya göre katılımcılar çevre dostu olduklarını söyleyen markalara inanmamakta ve çevreci reklamları abartılı bulmaktadır. Güsan ve arkadaşlarının $(2016$, s. 12) yapmış olduğu araştırmaya göre de katılımcılar çevreci ürünler ve markalarla ilgili yeterli bilgive sahip değildirler. Araştırmaya göre katılımcılar çevre dostu markaları sadece geleneksel medya aracılığıyla öğrenmektedir. Fakat bu durum da tüketiciler için yeterli olmamaktadır. Bunların yanı sıra Hassan ve Valenzuela'nın $(2016$, s. 176) yapmış olduğu çalışmaya göre de katılımcıların sadece \%29,6'sı çevre dostu markaların reklamlarından etkilenmektedir. Araştırmaya göre çevreci reklamlardan genellikle çevreyle ilgili farkındalık düzeyleri yüksek ve empati davranışı sergileyebilen tüketiciler etkilenmektedir. Ayrıca Ulusu ve Köksal'ın (2012, s. 4666) yapmış olduğu araştırmaya göre tüketicilerin çevreci reklamlardan etkilenme düzeyleri demografik özellikleri bağlamında değişiklik göstermektedir. Araştırmaya göre çevreci reklamlar, kadın ve yüksek gelire sahip tüketiciler üzerinde daha fazla etkilidir. Ayrıca araştırmada katılımcıların anne ve babalarının eğitim seviyesinin bireylerin çevreci reklamlara yönelik tutumunu etkilemediği gibi düşük gelire sahip bireylerde de bu reklam türü başarııı olamamaktadır. Benli, Karaosmanoğlu ve Taș'ın (2017, s. 253) yapmış olduğu araştırmaya göre de kadın tüketiciler çevreci reklamlara karşı daha duyarıdır. Ayrıca katıımcıların medeni durumlarıyla çevreci reklamlara olan tutumları arasında farklılıklar bulunmaktadır. Elde edilen verilere göre bekar katıımcılar, evlilere oranla çevreci reklamlara daha az itibar etmektedir. Bunun yanı sıra araştırmaya göre evli katılımcılar, bekarlara oranla daha çok çevreci markaları satın alma davranışı sergilemektedir. Karaca'nın (2013, s. 109) yapmış olduğu araştırmaya göre de katıımcıların demografik özellikleri ile çevre dostu markaları satın alma davranışları arasında fark olduğu görülmektedir. Araştırmada katıımcıların yaşları, cinsiyetleri, medeni durumları, eğitim düzeyleri ve meslek değişkenleri açısından fark bulunurken, gelir durumları değişkenleri arasında anlamlı bir farklıık bulunmamıştır. Fakat araştırmada katıımcıların demografik özellikleriyle doğa dostu ürün bilinci arasında anlamlı herhangi bir farklılık elde edilmemiştir. Tüketicilerin çevreci reklamlara olan tutumları ürün kategorisine göre de değişiklik göstermektedir. Alnıaçık ve arkadaşlarının (2010, s. 101) yapmış olduğu araştırmaya göre katılımcıların çevreci olduğunu iddia eden çamaşır makinesi reklamına karşı olumlu tutumları bulunmazken; katılımcılar çevreci mesajları olan kol saati ve DVD oynatıcı reklamlarına karşı ise olumlu tutum sergilemektedir. Katılımcıların, çevreci 
iddialara sahip olan çamaşır makinası reklamlarına ve markaya yönelik tutumları ile satın alma niyeti arasında anlamlı bir farklıık bulunmamaktadır. Ayrıca katılımcıların reklama olan inanılırlık düzeyleri düşüktür. Araştırmada bunun sebebi olarak çamaşır makinasının işlevsel faydasının dışında su ve enerji tasarrufu gibi özelliklerinin anlatılması katılımcıları olumsuz etkilemesi gösterilmektedir. Fakat katılımcılar DVD oynatıcı ve kol saati reklamlarındaki çevreci mesajlara daha olumlu yaklaşmaktadır. Bu bağlamda çevreci reklamlarda markaların ürün kategorisinin tüketicilerin tutumlarını değiştirdikleri söylenebilir. Bu sebeple markalar çevreci reklamlar yaparken ürünlerini dikkatli seçmelidir. Ayrıca tüketiciler reklamlardaki çevreci mesajların belirgin olup olmamasına göre de farklı tepkiler göstermektedir. Reklamlardaki çevreci iddiaların belirginlik düzeyleri azaldıkça, tüketicilerin reklamlara yönelik tutumları da olumludan olumsuza doğru değişmektedir (Davis, 1993, s. 23). Fakat Carlson ve arkadaşlarına (1993, s. 27) göre tüketiciler markaların çevresel faydalarını öven iddiaları yanıltıcı ve aldatıcı bulmaya yatkındır. Bu sebeple önemli olan tüketicilerin markaların çevre dostu iddialarına güvenmesi, markaların da çevre dostu davranışlar sergilemesi gerektiğidir (Karna, Juslin, Ahonen, \& Hansen, 2001, 5. 69).

\section{ARAŞTIRMANIN AMACI, KISITLARI, TÜRÜ ve HIPOTEZLERI}

Günümüzde tüketiciler çevre konularına karşı bilinçli davranmaktadır. Bilinçlenme, tüketim davranışlarına yansımakta, tüketiciler tüketmeme veya az tüketme davranışları sergilemektedir. Bu durum da tüketim karşıtlığı konusunun önemini arttırmaktadır.

Aşağıda yer alan hipotezler Nepomuceno ve Laroche'un (2015), Tariq'un (2014), Haytko ve Matulich'in (2008), Tas,ın (2020), Straughan ve Roberts'ın (1999) çalışmalarından yararlanılarak oluşturulmuş̧tur.

H1a: Tüketicilerdeki materyalizm eğilimi ile çevreci reklamlara olan tutumları arasında anlamlı bir ilişki vardır.

H1b: Tüketicilerdeki materyalizm eğilimi ile yeşil marka bilinçleri arasında anlamlı bir ilişki vardır.

H1c: Tüketicilerdeki materyalizm eğilimi ile çevreci ürünleri satın alma niyetleri arasında anlamlı bir ilişki vardır.

H2a: Tüketicilerdeki tutumluluk eğilimi ile çevreci reklamlara olan tutumları arasında anlamlı bir 
ilişki vardır.

H2b: Tüketicilerdeki tutumluluk eğilimi ile yeşil marka bilinçleri arasında anlamlı bir ilişki vardır.

H2c: Tüketicilerdeki tutumluluk eğilimi ile çevreci ürünleri satın alma niyetleri arasında anlamlı bir ilişki vardır.

H3a: Tüketicilerdeki gönüllü sadeleşme eğilimi ile çevreci reklamlara olan tutumları arasında anlamlı bir ilişki vardır.

H3b: Tüketicilerdeki gönüllü sadeleşme eğilimi ile yeşil marka bilinçleri arasında anlamlı bir ilişki vardır.

H3c: Tüketicilerdeki gönüllü sadeleşme eğilimi ile çevreci ürünleri satın alma niyetleri arasında anlamlı bir ilişki vardır.

\section{Araştırmanın Metodolojisi}

Günümüzde tüketiciler çevre konularına karşı bilinçli davranmakta, bu durum tüketim davranışlarına da yansımaktadır. Tüketiciler, tüketmeme veya az tüketme davranışları sergilemektedir. Ayrıca çevreyi koruyan ürünlere yönelmektedirler. Bu bağlamda araştırmada tüketim karşıtı olan tüketicilerin materyalizm, tutumluluk ve gönüllü sadeleşme eğilimlerinin çevreci reklamlara, yeşil marka bilincine ve çevreci ürün satın alma niyetleri arasındaki ilişki irdelenmiştir. Bu amaç doğrultusunda araştırmada Nepomuceno ve Laroche'un (2015) The impact of materialism and anti-consumption lifestyles on personal debt and account balances ve Tariq'nin (2014) Impact of green advertisement and green brand awareness on green satisfaction with mediating effect of buying behavior adlı çalışmalarından yararlanılmıştır. Araştırmada ölçeklerin faktör analizi yapıımış; ölçüm modelinin güvenilirliği ve geçerliliği test edilmiştir. Ayrıca araştırmada regresyon analizi ile etki düzeyleri belirlenmiş̧tir. Bunların yanı sıra araştırmaya katılan katıımcıların demografik değişkenlerini belirlemek amacıyla frekans ve yüzdeler kullanıımıştır. Verilerin analizinde SPSS 25.0 paket programı kullanılmıştır.

Araştırmada verilerin kolay toplanabilmesini sağlamak amacıyla kolayda örnekleme yöntemi (Kurtuluş, 2010, s. 63) tercih edilmiştir. Hızlı ve kolay veri elde edilebilmek ve zaman maliyet kısıtlamalarından dolayı araştırmanın ana kütlesini sadece İstanbul'da bulunan, tüketim karşıtı felsefeyi benimsemiş dayanışma merkezlerindeki üyeler oluşturmaktadır. Çarşamba günleri Tepebaşı'nda bir 
araya gelen ve cumartesi günleri ise Kadıköy'de buluşan tüketim karşıtı bireyler israf etmeden kullanılabilen ürünler aracılı̆̆ıyla yemek yapıp, çevrelerindeki insanlara dağıtmaktadır. Bu bireylerin hayat felsefesi doğayı korumak ve israfı önlemektir (Ersoy, 2015). Bu bağlamda araştırmada veri toplama tekniği olarak anket kullanılmış; araştırmanın örneklemini 389 kişi oluşturmuştur. ${ }^{1}$

\section{Bulgular ve Değerlendirilmeler}

Araştırmanın bu bölümünde, elde edilen bulgular analiz edilmekte ve problemin çözümüne yönelik açıklamalar yer almaktadır.

Tablo 1 Demografik Özellikler

\begin{tabular}{llll}
\hline & & $\mathbf{n}$ & $\%$ \\
\hline \multirow{2}{*}{ Cinsiyet } & Kadın & 307 & 78,9 \\
& Erkek & 82 & 21,1 \\
& İlkokul & 9 & 2,3 \\
En son mezun olunan eğitim & Ortaokul & 6 & 1,5 \\
kurumu & Lise & 82 & 21,1 \\
& Ön lisans & 12 & 3,1 \\
& Lisans & 174 & 44,7 \\
Medeni durum & Yüksek Lisans & 106 & 27,2 \\
& Bekar & 189 & 48,6 \\
Çalışma durumu & Evli & 200 & 51,4 \\
& Evet & 211 & 54,2 \\
Yaş & Hayır & 178 & 45,8 \\
Hane Toplam Gelir Durumu & & Ort \pm Ss & Min-Max (Medyan) \\
\hline
\end{tabular}

Araştırmaya katılan katıımcıların, \%78,9'u ( $n=307)$ kadın ve \%21,1'i ( $n=82)$ erkektir. Katıımcıların en son mezun oldukları eğitim kurumlarının \%2, 3'ü $(n=9)$ ilkokul, \%1,5'i $(n=6)$ ortaokul, \%21,1'i (n=82) lise, \%3,1'i ( $n=12)$ ön lisans, \%44,7'si ( $n=174)$ lisans ve \%27,2'si ( $n=106)$ yüksek lisanstır. Ayrıca araştırmadaki katılımcıların, \%48,6'sı ( $n=189)$ bekar ve \%51,4'ü ( $n=200)$ ise evlidir. Katılımcıların, \%54,2'si (n=211) çalışıyorken, \%45,8'i ( $n=178$ ) çalışmıyordur. Araştırmada katılımcıların yaşları da sorulmuştur. Elde edilen verilere göre katıımcıların yaşları 18 ile 75 arasında değişmekte olup, ortalama 40,23ะ13,3'dür. Katılımcıların gelir durumları 500 TL ile 15.000 TL değişmekte olup, ortalama 10.669,41 \$14.742,94'dür.

1 Serekan (2002) belli popülasyon büyüklükleri için örneklem büyüklüklerinin sayılarını tablo olarak vermektedir. Oluşturduğu tabloya göre, 1000000 kişilik bir grup iç̧in uygun örneklem sayısı 384 olarak belirlenmiştir. Bu veriye göre araştırmadaki örneklem hacmi uygundur. 
Tablo 2 Ölçek Alt Boyut Faktör Sonuçları ve KMO değerleri

\begin{tabular}{|c|c|c|c|c|c|}
\hline Ölçekler/Alt Ölçekler & $\begin{array}{l}\text { Ifade } \\
\text { Sayısı }\end{array}$ & Özdeğeler & $\begin{array}{l}\text { Varyansı } \\
\text { Açıklama } \\
\text { Oranı (\%) }\end{array}$ & $\begin{array}{l}\text { Kümülâtif } \\
\text { Varyans } \\
(\%)\end{array}$ & $\begin{array}{l}\text { Kaiser- } \\
\text { Meyer-Olkin }\end{array}$ \\
\hline Tüketim Karşıtı Ölçeği & 34 & & & & 0,782 \\
\hline Materyalizm & 17 & 7,812 & 22,977 & 22,977 & \\
\hline Tutumluluk & 8 & 4,203 & 12,363 & 35,340 & \\
\hline Gönüllü sadeleşme & 9 & 2,603 & 7,657 & 42,997 & \\
\hline Çevreci Reklamlar Ölçeği & 48 & & & & 0,797 \\
\hline Çevreci reklam & 33 & 13,906 & 28,970 & 28,970 & \\
\hline Yeşil marka bilinci & 5 & 4,261 & 8,878 & 37,848 & \\
\hline Çevreci ürünleri satın alma & 10 & 3.096 & 6,449 & 44,297 & \\
\hline
\end{tabular}

Araştırmada faktör analizinin uygulanabilirliğinin ölçümü için uygulanan Kaiser-Meyer-Olkin (KMO) adlı yeterlilik ölçümü ve Bartlett's Küresellik adlı testlerdir. Kaiser-Meyer-Olkin yeterlilik ölçümü 1'e ne kadar yakınsa eldeki bulgu grubuna faktör analizinin yapılması uygun bulunmaktadır (Çokluk, Şekercioğlu \& Büyüköztürk, 2012, s.207). Araştırmada hesaplanan Kaiser-Meyer-Olkin (KMO) yeterlilik ölçümüne ve Bartlett's Küresellik testi sonuçlarına göre veri gruba analiz yapılmasının uygun olduğu belirlenmiştir. Tüketim karşıtı ölçeği faktör analizi sonuçlarına göre üç faktörden oluşmakta olup, ölçeğin toplam varyans açıklama oranı 42,997 olarak hesaplanmıştır. Araştırmada kullanılan çevreci reklam ölçeği faktör analizi sonuçlarına göre ise ölçek üç faktörden oluşmakta ve toplam varyans açıklama oranı 44,297 olarak tespit edilmiştir.

Tablo 3 Ölçeklere İlişkin İçsel Tutarlılık Katsayıları

\begin{tabular}{lllll}
\hline & ifade Sayısı & $\begin{array}{l}\text { Cronbach's } \\
\text { Alpha }\end{array}$ & Skewness & Kurtosis \\
\hline Tüketim Karşıtı Ölçeği & $\mathbf{3 4}$ & $\mathbf{0 , 8 8 3}$ & & \\
Materyalizm & 17 & 0,860 & 0,086 & $-0,320$ \\
Tutumluluk & 8 & 0,790 & $-0,545$ & 0,406 \\
Gönüllü basitlik & 9 & 0,744 & $-0,299$ & $-0,429$ \\
Çevreci Reklamlar Ölçeği & $\mathbf{4 8}$ & $\mathbf{0 , 9 3 8}$ & & \\
Çevreci reklam & 33 & 0,915 & $-1,465$ & 6,567 \\
Yeşil marka bilinci & 5 & 0,896 & $-0,309$ & 0,870 \\
Çevreci ürünleri satın alma & 10 & 0,891 & $-0,458$ & $-0,219$ \\
\hline
\end{tabular}

Yukarıdaki Tablo 3'de araştırmada kullanılan tüketim karşıtlığı ve çevreci reklamlar ölçeklerinin içsel tutarlııklarına ilişkin Cronbach's Alpha değerleri yer almaktadır. Ölçeklerin Cronbach Alpha değerlerinin 0,70 ile 0,99 olması güvenilir olduğunu göstermektedir (Tavakol \& Dennick, 2011). Araştırmada elde edilen Cronbach's Alpha değerlerine göre ölçekler güvenilirdir. Ayrıca bir dağıımın 
normal bir dağıım gösterip göstermediğini belirlemek için çarpıklık ve basıklık değerleri dikkate alınmaktadır. Bu bağlamda "basıklık" ve "çarpıklık" değerlerinin kesme noktaları (sınırları) "çarpıklık" (Skewness) için "mutlak değer olarak 3" ve "basıklık" (Kurtosis) için "mutlak değer olarak 10'un" üzerinde olmamalıdır (Kline, 2011). Araştırmada elde edilen verilerin uygun olduğu görülmektedir.

Tablo 4 Tüketicilerin Materyalizm Eğilimleri Ile Çevreci Reklamlara Olan Tutum Illişkisi

\begin{tabular}{lllll}
\hline Katsayı & $\mathrm{B}$ & $\mathrm{S} . \mathrm{H}$. & $\mathrm{t}$ & $\mathrm{P}$ \\
\hline Sabit & 3,622 & 0,124 & 29,243 & $0,000^{* *}$ \\
Materyalizm & $-0,110$ & 0,03 & $-2,975$ & $0,001^{* *}$ \\
\hline ** $<0,01$ & & & &
\end{tabular}

Bağımsız değişken olarak ele alınan "materyalizm" ile bağımlı değişken olarak ele alınan "çevreci reklam" arasındaki basit doğrusal regresyon modeli, anlamlı bulunmuştur ( $\mathrm{p}=0,001 ;<0,01$; Adjusted $\mathrm{R}^{2}$ : 0,020). Bu bağlamda tüketicilerin materyalizm eğilimleri ile çevreci reklamlara olan tutumları arasında anlamlı bir ilişkinin olduğu söylenebilir. Elde edilen veriler sonucunda H1a hipotezi desteklenmektedir. Araştırmadaki verilere göre materyalizmdeki 1 birimlik artış, çevreci reklamlara olan tutumda 0,110 birimlik azalış yaratmaktadır. Diğer bir deyişle tüketicilerin materyalizm eğilimleri ile çevreci reklamlara olan tutumları arasında negatif bir ilişki vardır.

Tablo 5 Tüketicilerin Materyalizm Eğilimleri Ille Yeşil Marka Bilinci Ilişkisi

\begin{tabular}{lllll}
\hline Katsayı & $\mathrm{B}$ & $\mathrm{S} . \mathrm{H}$. & $\mathrm{t}$ & $\mathrm{P}$ \\
\hline Sabit & 4,299 & 0,199 & 21,591 & $0,000^{* *}$ \\
Materyalizm & $-0,315$ & 0,059 & $-5,320$ & $0,001^{* *}$ \\
\hline
\end{tabular}

${ }^{* *} p<0,01$

Bağımsız değişken olarak ele alınan "materyalizm" ile bağımlı değişken olarak ele alınan "yeşil marka bilinci" arasındaki basit doğrusal regresyon modeli, anlamlı bulunmuştur $(p=0,001 ;<0,01$; Adjusted $R^{2}:$ 0,066). Elde edilen verilere göre materyalizmdeki 1 birim artış, yeşil marka bilincinde 0,315 birimlik azalışa sebep olmaktadır. Bu bağlamda hipotez 1b'nin desteklendiği görülmektedir.

Tablo 6 Tüketicilerin Materyalizm Eğilimleri Ile Çevreci Ürünleri Satın Alma Niyetleri ilişkisi

\begin{tabular}{lllll}
\hline Katsayı & $\mathrm{B}$ & $\mathrm{S} . \mathrm{H}$. & $\mathrm{t}$ & $\mathrm{P}$ \\
\hline Sabit & 2,847 & 0,191 & 14,874 & $0,000^{* *}$ \\
Materyalizm & 0,195 & 0,057 & 3,419 & 0,514 \\
\hline
\end{tabular}

${ }^{* *} \mathrm{p}<0,01$

Bağımsız değişken olarak ele alınan "materyalizm" ile bağımlı değişken olarak ele alınan "çevreci ürünleri satın alma niyeti" arasındaki basit doğrusal regresyon modeli, anlamlı bulunmuştur $(p=0,001$; 
$<0,01$; Adjusted R²: 0,066). Materyalizmin satın alma üzerinde istatistiksel olarak anlamlı bir ilişki vardır. Diğer bir deyişle materyalizmdeki 1 birim artışı çevreci ürünleri satın alma niyeti için 0,195 birim artış yaratmaktadır. Bu bağlamda hipotez H1c'nin desteklenmektedir.

Tablo 7 Tüketicilerin Tutumluluk Eğilimleri Ile Çevreci Reklamlara Olan Tutum ilişkisi

\begin{tabular}{lllll}
\hline Katsayı & B & S.H. & t & P \\
\hline Sabit & 2,669 & 0,146 & 18,337 & $0,000^{* *}$ \\
Tutumluluk & 0,162 & 0,039 & 4,102 & $0,001^{* *}$ \\
\hline$* * p<0,01$ & & & &
\end{tabular}

Bağımsız değişken olarak ele alınan "tutumluluk" ile bağımlı değişken olarak ele alınan "çevreci reklam" arasındaki basit doğrusal regresyon modeli, anlamlı bulunmuştur ( $\mathrm{p}=0,001 ;<0,01$; Adjusted $\mathrm{R}^{2}$ : 0,059). Araştırmada elde edilen verilere göre tutumluluktaki 1 birim artış, çevreci reklam için 0,162 birim artış yaratmaktadır. Bu bağlamda tüketicilerin tutumluluk eğilimleri ile çevreci reklama olan tutumları arasında anlamlı bir ilişki vardır hipotezi H2a desteklenmiştir.

Tablo 8 Tüketicilerin Tutumluluk Eğilimleri Ille Yeşil Marka Bilinci İlişkisi

\begin{tabular}{lllll}
\hline Katsayı & B & S.H. & t & p \\
\hline Sabit & 3,118 & 0,245 & 12,739 & $0,000^{* *}$ \\
Tutumluluk & 0,038 & 0,066 & 0,576 & 0,565 \\
\hline
\end{tabular}

${ }^{* *} \mathrm{p}<0,01$

Bağımsız değişken olarak ele alınan "tutumluluk" ile bağımlı değişken olarak ele alınan "yeşil marka bilinci" arasındaki basit doğrusal regresyon modeli, anlamlı bulunmamıştır $(p>0,05)$. Diğer bir deyişle tutumluluğun yeşil marka bilinci üzerinde istatistiksel olarak anlamlı bir etkisi yoktur. Bu bağlamda tüketicilerin tutumluluk eğilimleri ile yeşil marka bilinçleri arasında anlamlı bir ilişki yoktur. Bu sebeple hipotez H2b'nin desteklenmediği söylenebilir.

Tablo 9 Tüketicilerin Tutumluluk Eğilimleri Ille Çevreci Ürünleri Satın Alma Niyetleri Illişkisi

\begin{tabular}{lllll}
\hline Katsayı & $\mathrm{B}$ & $\mathrm{S} . \mathrm{H}$. & $\mathrm{t}$ & $\mathrm{p}$ \\
\hline Sabit & 1,915 & 0,216 & 8,868 & $0,000^{* *}$ \\
Tutumluluk & 0,431 & 0,058 & 7,385 & $0,001^{* *}$ \\
\hline
\end{tabular}

${ }^{* *} \mathrm{p}<0,01$

Bağımsız değişken olarak ele alınan "tutumluluk" ile bağımlı değişken olarak ele alınan "çevreci ürünleri satın alma niyeti" arasındaki basit doğrusal regresyon modeli, anlamlı bulunmuştur ( $p=0,001$; 
$<0,01 ;$ Adjusted $\left.R^{2}: 0,121\right)$. Diğer bir deyişle tutumluluktaki 1 birim artışı, çevreci ürünleri satın alma niyeti için 0,431 birim artış yaratmaktadır. Bu bağlamda araştırmadaki hipotez $\mathbf{H 2 c}$ desteklenmektedir.

Tablo 10 Tüketicilerin Gönüllü Sadeleşme Eğilimleri İle Çevreci Reklamlara Olan Tutum Illişkisi

\begin{tabular}{lllll}
\hline Katsayı & B & S.H. & t & P \\
\hline Sabit & 3,010 & 0,142 & 21,253 & $0,000^{* *}$ \\
Gönüllü sadeleşme & 0,076 & 0,043 & 1,783 & 0,075 \\
\hline
\end{tabular}

${ }^{*} p<0,05$

Bağımsız değiş̧ken olarak ele alınan "gönüllü sadeleşme" ile bağımlı değişken olarak ele alınan "çevreci reklamlar" arasındaki basit doğrusal regresyon modeli, anlamlı bulunmamıştır $(p>0,05)$. Diğer bir deyişle tüketicilerin gönüllü sadeleşme eğilimleriyle çevreci reklamlara olan tutumları arasında anlamlı bir ilişki yoktur. Elde edilen veriler sonucunda hipotez H3a desteklenmemektedir.

Tablo 11 Tüketicilerin Gönüllü Sadeleşme Eğilimleri İle Yeşil Marka Bilinci İlişkisi

\begin{tabular}{lllll}
\hline Katsayı & B & S.H. & T & P \\
\hline Sabit & 3,118 & 0,245 & 12,739 & $0,000^{* *}$ \\
Gönüllü sadeleşme & 0,038 & 0,066 & 0,576 & 0,995 \\
\hline
\end{tabular}

${ }^{* *} \mathrm{p}<0,01$

Bağımsız değişken olarak ele alınan "gönüllü sadeleşme" ile bağımlı değişken olarak ele alınan "yeşil marka bilinci" arasındaki basit doğrusal regresyon modeli, anlamlı bulunmamıştır $(p>0,05)$. Diğer bir deyişle gönüllü sadeleşmenin yeşil marka bilinci üzerinde istatistiksel olarak anlamlı bir etkisi yoktur. Bu sebeple hipotez H3b desteklenmemektedir.

Tablo 12 Tüketicilerin Gönüllü Sadeleşme Eğilimleri Ile Çevreci Ürünleri Satın Alma Niyetleri Iliş̧kisi

\begin{tabular}{lllll}
\hline Katsayı & B & S.H. & $T$ & $P$ \\
\hline Sabit & 1,913 & 0,206 & 9,447 & $0,000^{* *}$ \\
Gönüllü sadeleşme & 0,471 & 0,062 & 7,622 & $0,001^{* *}$ \\
\hline
\end{tabular}

${ }^{* *} p<0,01$

Bağımsız değişken olarak ele alınan "gönüllü sadeleşme" ile bağımlı değişken olarak ele alınan "çevreci ürünleri satın alma niyeti" arasındaki basit doğrusal regresyon modeli, anlamlı bulunmuştur ( $p=0,001 ;<0,01$; Adjusted R2: 0,128). Diğer bir deyişle gönüllü sadeleşmedeki 1 birim artışı çevreci ürünleri satın alma niyeti için 0,471 birim artış yaratmaktadır. Bu bağlamda araştırmadaki hipotez H3c desteklenmektedir. 


\section{SONUÇ}

Günümüzde tüketim hızlıca ve daha çok duygusal nedenlere bağlı olarak artmaktadır. Ürünlerin rasyonel faydalarından ziyade haz amacı güden tüketiciler, tüketim davranışlarında aşırıya kaçmaktadır. Bu durum çevrenin kirlenmesine, doğal hayatın riske girmesine ve doğal kaynakların hızla tükenmesine sebep olmaktadır. Fakat tüketimdeki bu kontrolsüz ve hızlı artış, bazı tüketicilerin dikkatini çekmekte ve tepki vermelerine sebep olmaktadır. Aşırı ve kontrolsüz tüketime karşı çıkan bireyler, tüketim kültürüne ve onun oluşturduğu anlamlara karşı durmaktadır. Genellikle tutumlu davranışlar sergileyen tüketim karşıtları, minimal bir yaşam tarzına sahip olup, gönüllü olarak sade bir hayat sürmektedir. Bu bağlamda gereksiz tüketime direnmekte, tasarruf etmekte ve kaynaklarını korumakta veya dönüştürmektedir. Diğer bir deyişle tüketim karşıtları kullanılabilir gördükleri, rasyonel özellikleri olan ürünleri tercih etmekte, bu ürünlerin ömürlerini uzatmaya çalışmakta, çoğu zaman bozulana kadar değiştirmemekte, bozulduğunda ise tamir etmeye çalışmaktadır. Tüketim karşıtları moda olduğu veya eskidiği için genellikle kullandıkları ürünleri değiştirmezler. Bu bireyler çevre ve doğa olaylarına karşı da hassas davranmaktadır. Maddiyata önem vermeyen ve sadeliği tercih den tüketim karşıtları kullandıkları ürünlerde basit ambalaj, işlevsellik ve geri dönüşüm gibi özellikler aramaktadır. Bilinçli tüketim davranışı sergileyen, doğaya en az zararı vermek isteyen tüketiciler, seçtikleri markalardan da benzer davranışlar sergilemelerini istemektedir.

Özellikle 1980 li yılların sonlarına doğru çevre ve toplumsal olaylara olan farkındalık artmıştır. Tüketicilerdeki bu bilinçlenme markaların da doğayı korumaya yönelik çevreci reklamlara yönelmesine sebep olmuştur. Doğa sorunlarına dikkat eden, kirlenmeyi önlemeye veya iyileştirmeye çalışan markalar bu iddialarını çevreci reklamlarıyla tüketicilere iletmektedir. Markalar genellikle 'yeniden kullanılabilir', 'çevre dostu' ve 'daha az atık' ifadeleri kullandıkları çevreci reklamlarıyla, hedef kitlelerinin algılarını değiştirmekte, bilinç oluşturmakta ve böylece satın alma gerçekleşmektedir. Doğayı koruduğunu iddia eden markaların yapmış oldukları reklamlarla tüketicilerin dikkatini çektiği söylenebilir.

Bu bağlamda araştırmanın temel amacı tüketim karşıtı olan tüketicilerin materyalizm, tutumluluk ve gönüllü sadeleşme eğilimleri ile çevreci reklamlar yeşil marka bilinci ve çevreci ürün satın alma niyetleri arasında anlamlı bir ilişinin olup olmadığını irdelemektir. Bu sebeple araştırmada tüketim karşıtı tüketicilerin materyalizm, tutumluluk ve gönüllü sadelik düzeyleri ölçülmüştür. Ayrıca 
katıımcıların çevreci reklamlara olan tutumları, yeşil marka bilinçleri ve çevreci ürünlere olan satın alma davranışları da belirlenmiştir. Elde edilen sonuçlara göre materyalizm eğilimine sahip tüketicilerin çevreci reklamlarla negatif yönde bir ilişkisi bulunmaktadır. Diğer bir deyişle materyalist eğilimler gösteren tüketicilerin, çevreci reklamlara olan tutumları olumsuzdur. Ayrıca bu eğilime sahip bireyler ile yeşil marka bilinçleri arasında da negatif bir ilişki vardır. Bu ilişkiye göre materyalizm eğilimine sahip bireylerin yeşil marka bilinci azdır. Ancak diğer yandan materyalizm eğilim ile çevreci ürünleri satın alma niyetleri arasında pozitif bir ilişki bulunmuştur. Elde edilen sonuçlara göre tüketicilerin materyalizm eğilimleri arttıkça, çevreci ürünleri satın alma niyetleri de artmaktadır. Bu bağlamda tüketicilerin çevreci ürünleri satın almasında çevreci reklamların ve yeşil marka bilincinin etkili olmadığı söylenebilir. Bu sebeple materyalizm eğilimine sahip bireylerin çevreci ürünleri satın almasının sebebi olarak fiyat, ulaşım kolaylı̆̆ı vb. Farklı değişkenlerin işlevsel olduğu düşünülebilir. Bunların yanı sıra araştırmada tutumluluk eğilimi gösteren katılımcıların, çevreci reklamlara olan tutumları ve çevreci ürünleri satın alma niyetleri arasında da anlamlı bir iliş̧ki bulunmuştur. Fakat katılımcıların bu eğilimleriyle yeşil marka bilinçleri arasında anlamlı bir ilişki yoktur. Araştırmada son olarak gönüllü sadeleşme eğilimine sahip bireylerle ilgili elde edilen veriler incelenmiştir. Bulgulara göre gönüllü sadeleşme eğilimindeki katılımcılar, çevreci ürünleri satın almaya daha meyillidir. Fakat bu eğilime sahip katılımcıların çevreci reklamlara ve yeşil marka bilincine dair bir ilişki yoktur.

Araştırmada elde edilen bulguların markaların, tüketicilerin tutum ve davranışlarını daha iyi anlamasına yardımcı olacağı düşünülmektedir. Elde edilen verilerin, markaların çevreci mesajlar içeren reklam stratejilerini belirlerken yol gösterici olacağına inanılmaktadır. Tüketicinin tutum ve davranışlarını anlayan markalar, iletişim çalışmalarını araştırmada elde edilen verilere uygun olarak geliştirebilir. Ayrıca çalışmanın literatüre de katkı sağladığına inanılmaktadır. Bu bağlamda çalışmanın gelecek yıllarda daha farklı demografik özelliklere, kültüre, tutum ve davranışa sahip tüketicilere yapılacak araştırmalara da ışık tutacağı düşünülmektedir.

\section{EXTENDED ABSTRACT}

Today, with capitalism, consumers are overconsumption. In this context, consumers generally do not act in line with their rational benefits, they aim to enjoy their consumption. Individuals who consume in line with this purpose go to extremes in their behavior. This situation may cause 
environmental pollution, risk of natural life and destruction of resources. In other words, the endless demands and excessive consumption of consumers can cause natural disasters. However, these problems caused by excessive and unconscious consumption attract the attention of some consumers and disturb them. These consumers do not enjoy consuming, resist consumption and even have negative emotions such as anger towards consumption. These anti-consumption individuals correspond to the consumption culture and the meanings of consumption. These individuals generally oppose materialism and tend towards voluntary simplicity. Consumers who adopt minimalism behave conservatively in their consumption. Opponents of consumption resist consumption, mysticize and protect their resources. In addition, these individuals who have adopted the non-consuming philosophy try to extend the life of the products they use, repair the damaged ones or reuse them in different areas by making changes in the product. Consumers who do not attach importance to materials and adopt a simple and minimal lifestyle prefer products with simple packaging, high functionality and rational benefit. In other words, opponents of consumption exhibit conscious consumption behavior, pay attention to carbon footprints and try to generate less waste. In this context, consumer opponents, who act frugally, choose voluntary simplification and have a minimal lifestyle, prefer local products, tend to organic products, prefer green energy companies and use green brands because of their concern for ethical, symbolic and nature. With the awareness of consumers, the fact that they are more sensitive to environmental issues attracts the attention of brands. This situation causes brands to develop environment-oriented strategies. Especially after the 80's, the increased awareness of environmental and social events has also increased the number of environmentalist advertisements aimed at protecting nature. For environmental advertisements, ads that take into account the nature problems and make claims to prevent or improve environmental pollution can be defined. In other words, environmental advertisements can be called advertisements where the brand conveys the message that it takes environmental responsibility, either explicitly or implicitly. In such advertisements, expressions such as "less waste", "environmentally friendly", "recyclable" or "recyclable" are usually used to indicate that the brand is environmentally friendly. Thus, environmental advertisements change the perception of the target audience, create awareness and ensure the purchase of the brand. However, consumers may find claims praising the environmental benefits of brands misleading or deceptive. For this reason, it is important for consumers to believe and trust in brands' claims to be environmentally friendly. It can be said that advertisements 
claiming to protect the environment also attract the attention of anti-consumer consumers. It can be thought that the awareness of the opponents of consumption, who exhibit consumption behavior towards protecting nature, is higher about the environment.

In the light of the above information, the main purpose of the study is to examine whether there is a meaningful relationship between the sub-dimensions of consumer opposition, such as materialism, frugality and voluntary simplification, and their attitudes towards environmental advertisements, green brand awareness, and environmental product purchase intentions. For this purpose, data were obtained from 389 participants through a questionnaire. According to the results of the study, there is a negative relationship between the consumers with materialism tendencies and environmental advertisements. In other words, consumers who show materialistic tendencies have less attitude towards environmentally friendly advertising. In addition, there is a negative relationship between individuals with this tendency and green brand awareness. According to this relationship, individuals with materialism tendencies have little green brand awareness. However, according to the data obtained in the research, there is a positive relationship between the people who have materialism tendencies and their intention to buy environmentally friendly products. In other words, as the materialism tendency of consumers increases, their intention to purchase environmentally friendly products also increases. In the study, a significant relationship was also found between the attitudes of the participants with thrifty tendencies towards environmentally friendly advertising and their intention to purchase environmentally friendly products. However, there is no significant relationship between these tendencies of the participants and their green brand awareness. In addition to these, a significant relationship was found between the voluntary simplification tendency of the participants to purchase environmental products. However, there is no relationship between the participants who have this tendency regarding environmental advertisements and green brand awareness.

By looking at the anti-consumption tendencies of the research, it is believed that determining whether there are relationships between attitudes towards environmentally friendly advertisements, green brand awareness and purchasing behaviors for environmentally friendly products will guide the brands in determining strategies. Brands that understand the attitudes and behaviors of the consumer can develop their marketing studies in accordance with the results of this research. In addition, it is thought that the study will shed light on the future researches. 


\section{KAYNAKÇA}

Albinsson, P. A., Wolf, M., \& Kopf, D. A. (2010). Anti-consumption in East Germany: Consumer resistance to hyperconsumption. Journal of Consumer Behaviour, 9, 412-425.

Alnıaçık, Ü. (2009). Tükericilerin çevreye duyarlılığı ve reklamlardaki çevreci iddialar. Kocaeli Üniversitesi Sosyal Bilimler Enstütüsü Dergisi, 18 (2), 48-79.

Alnıaçık, Ü., Yılmaz, C., \& Alnıaçık, E. (2010). Reklamlarda çevreci iddialar ve reklam etkililiği: Basılı reklamlar üzerinde deneysel bir araştırma. Anadolu Üniversitesi Sosyal Bilimler Dergisi , 10 (1), 85106.

Banerjee, S., Gulas, C. S., \& Iyer, E. (1995). Journal of Advertising. Shades of green: a multidimensional analysis of environmental advertising, 24 (2), 21-31.

Basci, E. (2014). A revisited concept of anti-consumption for marketing. International Journal of Business and Social Science, 5(7), 160-168.

Belk, R. W. (1984). Three scales to measure constructs related to materialism reliability, validity and relationships to measures of happiness. Advances in Consumer Research, 11 (1), 291-297.

Benli, T., Karaosmanoğlu, K., \& Taş, Ö. (2017). Çalışan bireylerin yeşik ürün reklamlarına yönelik tutumlarını etkileyen faktörlerin demografik özelliklerine göre farklılıkları. BMIJ , 5(4), 235-256.

Black, I. R., \& Cherrier, H. (2010). Anti-consumption as part of living a sustainable lifestlye: daily practice, contextual motivations and subjective values. Journal of Consumer Behavior , 9, 437-453.

Boujbel, L., \& D'astous, A. (2012). Voluntary simplicity and life satisfaction: exploring the mediating role of consumption desires. Journal of Consumer Behaviour, 11, 487-494.

Carlson, L., Grove, S. J., \& Kangun, N. (1993). A content analysis of environmental advertising claims: a matrix method approach . Journal of Advertising , 22 (3), 27-39.

Chatzidakis, A., \& Lee, M. S. (2012). Anti-consumption as the study of reasons against. Journal of Macromarketing , 33 (3), 190-203.

Çam, M. S., \& Ürün, E. (2019). Sürdürülebilirlik ve yeşil markalar: Toyota örneği üzerine bir inceleme. Research Gate: file:///Users/yelda/Downloads/yesil-markalar.pdf adresinden alınmıştır

Daun, A. (1983). The materialistic life-style: some socio-psychological aspects. Consumer Behavior and Environmental Quality, 6-16.

Davis, J. J. (1993). Strategies for environmental advertising. Journal of Consumer Marketing, 10 (2), 19-36.

Dopierala, R. (2017). Minimalism- A new mode of consumption? Przeglad Sociologiczny, 66 (4), 67-83.

Ersoy, K. M. (2015, 06 03). Bomba değil, yemek: bombalara karşı sofralar. 01 01, 2021 tarihinde Gaia Dergisi: https://gaiadergi.com/bomba-degil-yemek-bombalara-karsi-sofralar/bombalarakarsi-sofralar/ adresinden alındı

Güsan, G., Aktaş, E., \& Güvendik, Ö. (2016). Yeşil ürün grupları çerçevesinde tüketici farkındalığı. Istanbul Journal of Social Sciences, 13, 1-16. 
Hassan, R., \& Valenzuela, F. (2016). Customer perception of green advertising in the context of ecofriendly FMCGS. Contemporary Management Research, 12 (2), 169-182.

Haytko, D. L., \& Matulich, E. (2008). Green advertising and environmentally responsible consumer behaviors: Linkages examined. Journal of Management and Marketing, 1, 2-11.

Iwata, O. (2006). An evaluation of consumerism and lifestyle as correlates of a voluntary simplicity lifestyle. Social Behavior and Personality, 34 (5), 557-568.

Karaboğa, T. (2016). Televizyon dizilerinde tüketim olgusu. International Journal of Human Sciences, 13(1), 2072-2101.

Karaca, Ş. (2013). Tüketicilerin yeşil ürünlere iliş̧kin tutumlarının incelenmesine yönelik bir araştırma. Ege Akademik Bakış, 13 (1), 99-111.

Karna, J., Juslin, H., Ahonen, V., \& Hansen, E. (2001). Green advertising: greenwash or a true reflection of marketing strategies? Greener Management International , 33, 59-70.

Kasser, T. (2005). Frugality, generosity, and materialism in children and adolescents. K. A. Moore, \& L. H. Lippman içinde, In What Do Children Need to Flourish? (s. 357-373). Boston MA: Springer.

Kaynak, R., \& Eksi, S. (2011). Ethnocentrism, religiosity, environmental and health consciousness: motivators for anti-consumers. Eurasian Journal of Business and Economics , 4 (8), 31-50.

Kline, R. B. (2011). Principles and Practice of Structural Equation Modelling (Cilt 3). New York: Guilford Press.

Kurtuluş, K. (2010). Araştırma Yöntemleri. İstanbul: Türkmen Kitabevi.

Lastovicka, J. L., Bettencourt, L. A., Hughner, R. S., \& Kuntze, R. J. (1999). Lifestyle of the tight and frugal: theory and measurement. Journal of Consumer Research, 26 (1), 85-98.

Lloyd, K., \& Pennington, W. (2020). Towards a theory of minimalism and wellbeing. International Journal of Applied Positive Psychology, 5, 121-136.

Nepomuceno, M. V., \& Laroche, M. (2015). The impact of materialism and anti-consumption lifestyles on personal debt and account balances. Journal of Business Research, 68 (3), 1-11.

Palafox, L. C. (2020). When less is more: minimalism and the environment. Environmental and Earth Law Journal, 10, 64-88.

Penaloza, L., \& Price, L. L. (1993). Consumer resistance: a conceptual overview. L. Mcalister, \& M. L. Rothschild içinde, NA - Advances in Consumer Research (Cilt 20, s. 123-128). Provo, UT: Association for Consumer Research.

Rahbar, E., \& Wahid, N. A. (2011). Inverstigation of green marketing tools' effect on concumers' purchase behavior. Business Strategy Series, 12 (2), 73-83.

Rick, S. I., Cynthia, C. E., \& Loewenstein, G. (2008). Tightwads and spendthrifts. Journal of Consumer Research, 34 (6), 767-782.

Serekan, U. (2002). Research Methods for Business: A Skill Building Approach (Cilt 4). USA: John Wiley \& Sons.

Shama, A. (1981). Coping with staglation: voluntary simplicity. Journal of Marketing, 45 (3), 120-134. 
Shaw, D., \& Moraes, C. (2009). Voluntary simplicity: an exploration of market interactions. International Journal of Consumer Studies, 33 (2), 215-223.

Straughan, R. D., \& Roberts, J. A. (1999). Environmental segmentation alternatives: a look at green consumer behavior in the new millennium. Journal of Consumer Marketing, 16 (6), 558-575.

Tariq, M. Z. (2014). Impact of green advertisement and green brand awareness on green satisfaction with mediating effect of buying behavior. Journal of Managerial Sciences, 8(2), 274-289.

Taş, S. (2020). Tüketim karşıtı yaşam tarzları: freeganizm, gönüllü sadelik ve minimalizm. Toplum ve Kültür Araştırmaları Dergisi, 6, 38-64.

Tavakol, M., \& Dennick, R. (2011). Making sense of cronbach's alpha. International Journal of Medical Education, 2, 53-55.

Ulusu, Y., \& Köksal, D. (2012). Yeşil reklama yönelik tutum: üniversite öğrencileri üzerine bir uygulama. Journal of Yasar University, 27 (7), 4642-4669.

Zavestoski, S. (2002). Guest editorial: anticonsumption attitudes. Psychology \& Marketing, 19 (2), $121-$ 126.

Zinkhan, G. M., \& Carlson, L. (1995). Green advertising and the reluctant consumer. Journal of Advertising , $24(2), 1-6$. 